24. Krishnan, B., Babu, S., Walker, J., Walker, A. B. and Pappachan, J. M., Gastrointestinal complications of diabetes mellitus. World $J$. Diab., 2013, 4(3), 51-63.

25. Gagner, M. and Buchwald, J. N., Comparison of laparoscopic sleeve gastrectomy leak rates in fourstaple-line reinforcement options: a systematic review. Surg. Obesity Relat. Dis., 2014, 10, 713-724; http://dx.doi.org/10.2147/MDER.S67338.

26. Ghosh, S. K., Roy, S., Chekan, E. and Fegelman, E. J., A narrative of intraoperative staple line leaks and bleeds during bariatric surgery. Obes. Surg., 2016, 26(7), 1601-1606; doi:10.1007/s11695016-2177-1.

27. Rosenthal, R. J., International sleeve gastrectomy expert panel consensus statement: best practice guidelines based on experience of $>12,000$ cases. Surg. Obes. Relat. Dis., 2012, 8, 8-19.

28. Sacks, M. S. and Sun, W., Multiaxial mechanical behavior of biological materials. Annu. Rev. Biomed. Eng., 2003, 5, 251-284; doi:10.1146/annurev.bioeng.5.011303.120714.

ACKNOWLEDGEMENT. This study was supported by the MN 010111/08 grant provided by the Medical University of Gdansk, Poland.

\section{Engendering finger millet-based value chains for livelihood and nutritional security of women in agriculture}

\author{
J. Charles Jeeva ${ }^{1, *}$, Kushagra Joshi ${ }^{2}$, \\ Abha Singh ${ }^{1}$ and B. C. Behera ${ }^{1}$ \\ ${ }^{1}$ ICAR-Central Institute for Women in Agriculture, \\ Bhubaneswar 751 003, India \\ ${ }^{2}$ ICAR-Vivekananda Parvatiya Krishi Anusandhan Sansthan, \\ Almora 263 601, India
}

Gender analysis along the agricultural value chain enhances our understanding about the roles performed by men and women in the value chain and in forward and backward linkages, their access to productive resources, opportunities available for valueaddition and benefit sharing, both as individuals and group enterprises. The gender roles in finger milletbased value chains and the constraints faced by women in existing finger millet value chains in Tamil Nadu, Karnataka and Odisha have been documented in this study. Along the value chains, women were found only as farmers, petty traders or labourers in processing units. However, the entry points for women in finger millet value chain have been identified. The role of women in the value chain could be strengthened by mobilizing them into clusters, establishing milletprocessing units, and forming forward and backward linkages.

\footnotetext{
*For correspondence. (e-mail: jcjeeva@gmail.com)
}

Keywords: Gender, finger millet, value chain, livelihood, nutritional security.

GENDER analysis along agricultural value chain enhances our understanding about the roles performed by men and women in the value chain. Secondary agriculture, more specifically the value chain development in agriculture provides a great opportunity for income enhancement, and it is very significant to recognize the position of women in the value chain for their socio-economic empowerment. Enhancing the participation of women in agricultural value chains will not only enhance their purchasing powers, but will also empower them by allowing participation in decision-making and access to resources.

Explicitly gendered studies of value chains have mostly been carried out with reference to the horticultural sector $^{1,2}$. Against this backdrop, the present study has been conducted with the objectives to examine and document the gender roles in finger millet (ragi)-based value chains, to study gender-based constraints faced by women and to identify entry points to strengthen their role in these value chains by forming forward and backward linkages.

The finger millet-based value chain has been selected for the present study, as the crop is considered as propoor, pro-nutrition and pro-women in nature. Secondary data on state-wise production of finger millet in Indian markets, different value-added products and the technologies available for its production and processing were collected. On the basis of this information, states were selected, markets identified, research instruments developed, technologies identified for action research and value-added products to be upscaled were also identified. The research instruments required for the study, i.e. the questionnaires for value-chain mapping and interview schedules for each value-chain actor were prepared on the basis of extensively collected secondary literature. Focused group discussions and in-depth household surveys were also conducted to collect the required data. The technology used in millet production, post-harvest processing, value-addition, nodes in the marketing chain and the role of women in different nodes along the value chain were studied. The sample size was 120 stakeholders contacted through snow-ball sampling technique, representing the farmer producers, retailers, wholesale traders and processors from Koraput district of Odisha, Tumkur district of Karnataka and Madurai district of Tamil Nadu (TN).

The channels for finger millet were mapped by visiting markets in the study area. Major functions mapped were input supply, production, processing, trading and consumption. Instead of starting with the farmers/production node, backward mapping of the chain was followed, i.e. the mapping process started with the industry involved in processing and marketing of value-added products of finger millet. Figure 1 shows the gendered roles in finger 


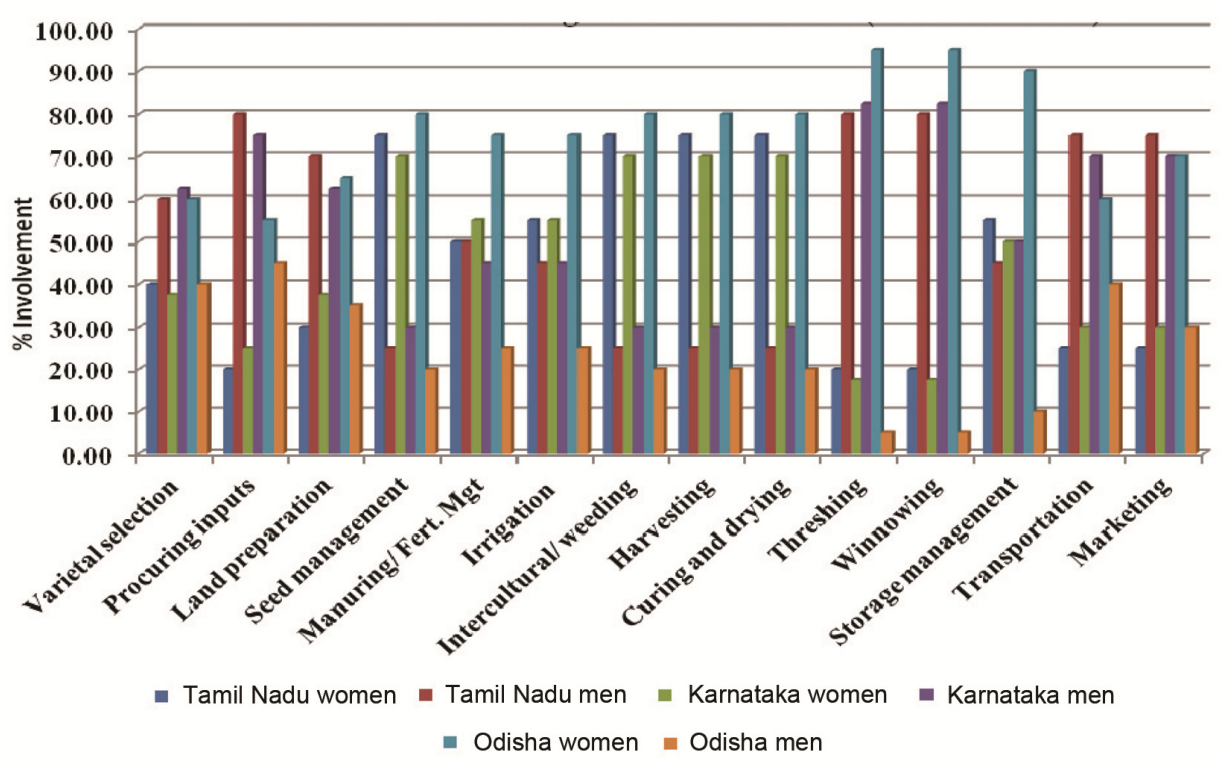

Figure 1. Gendered roles in finger millet production (\% involvement).

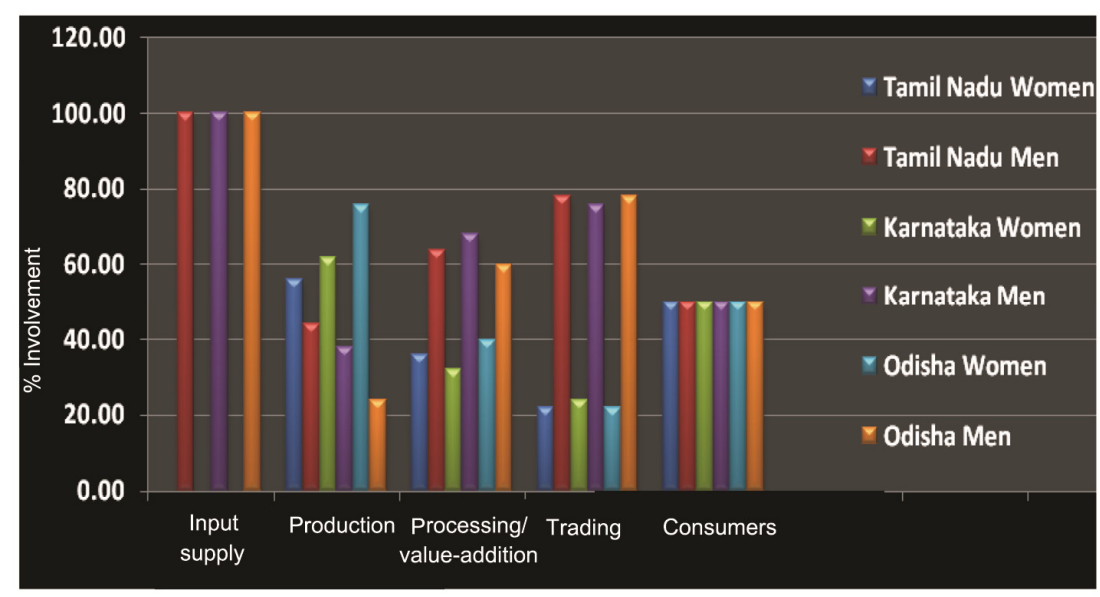

Figure 2. Gendered roles in finger millet value chain (\% involvement).

millet production as observed among the sample respondents from the three states.

In Odisha, the major activities performed by farm women in finger millet cultivation were varietal selection (60\%), land preparation (65\%), seed management (80\%), manuring $(75 \%)$, irrigation $(75 \%)$, intercultural operations and weeding $(80 \%)$, harvesting $(80 \%)$, curing and drying (80\%), threshing (95\%), winnowing (95\%), storage management $(90 \%)$, transportation $(60 \%)$ and marketing $(70 \%)$. About $70 \%$ of the farm women were involved in selling the produce either from farm gate or to middlemen. In Karnataka and TN, the participation of women in finger millet production was at a medium to low level, because of the mechanization involved. The major activities of women were seed management, weeding, harvesting, cleaning and drying the grain (70-75\%). There was less participation of women in marketing of the produce $(25-30 \%)$. Decisions on when, where and how much to sell were mostly taken by men.

Figure 2 shows the gendered roles in finger millet value chain observed in the three states.

In Karnataka and TN, the value chain was observed to be well-established, and an array of value-added finger millet products could be seen in the markets. More valueadded products were found in the markets of these two states, e.g. ragi malt, ragi health mix, flour, biscuits, ready-to-cook mixes, etc. In Odisha, the product diversification was confined to ragi flour only. The participation of women in finger millet value chain was also predominant in TN and Karnataka, as mostly women were seen as entrepreneurs. In Odisha, along the value chain, women were found as farmers, petty traders and labourers in processing units. Men were found as traders, middlemen, owners of mills and retailers/wholesalers of finger millet. 


\section{RESEARCH COMMUNICATIONS}

In the processing units, women were involved as workers for cleaning grains, feeding the mills, operating and collecting the flour, whereas men were involved in carrying loads, weighing, account-keeping and maintaining machineries.

Figure 3 shows the gender-based constraints in finger millet production/processing/marketing as perceived by the respondents.

The major constraints perceived were the socio-cultural constraints such as less value/appreciation to women's farm work, more household responsibilities, lack of supportive services like childcare, less mobility to markets; economic constraints such as credit constraints/less access to finance, low price of produce; technological constraints such as lack of appropriate skills, lack of women-friendly tools, less training contacts, tedious postharvest operations; and others such as less extension contact for women farmers, less access to information, and lack of market information, awareness, collection centres and cooperative societies. Further, other issues observed in establishing forward linkages with the markets were: the high commission charged by supermarkets, poor quality of raw materials, complex system of licensing and renewal, fluctuating prices of ragi and lack of awareness about nutritive value of ragi among the consumers.

Harvesting is done manually with the traditional sickle. Threshing is usually done in open threshing floors leading to high levels of contamination with foreign matter composed of stones, soil and plant matters. These can

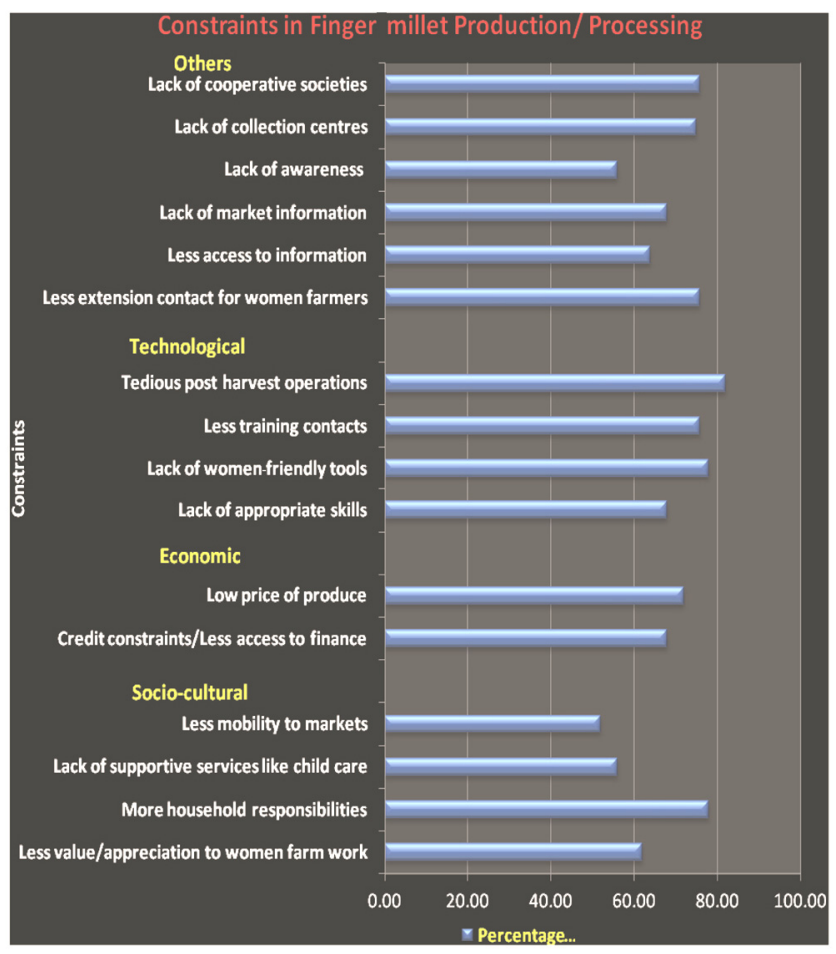

Figure 3. Constraints in millet production/processing/marketing. affect the quality of the grains, cause problems for the processor/traders, and as a result, occasionally lead to rejection of the poor-quality grains or lesser price for the primary produces. Among the post-production activities, threshing $(100 \%)$ and winnowing $(88 \%)$ were reported as the major drudgery-prone activities, followed by harvesting $(75 \%)$. The drudgery involved in finger millet threshing was quantified by taking heart rate measurements with a polar heart rate monitor and calculating energy expenditure. In threshing, it was recorded that women have to beat the finger millet panicles 25 times in a minute with a heavy wooden plank. The average working heart rate for finger millet threshing activity was found to be 133.36 beats/min, which labels the activity as a heavy one, with average energy expenditure as $12.48 \mathrm{~kJ} / \mathrm{min}$. Women manually beat the dried spikelet in scorching sun on earthen ground with big wooden logs. The repetitive nature of work with bent posture makes the activity more tedious and drudgery-prone. Moreover, the work environment during threshing and winnowing is full of husk and dust particles, which is hazardous and makes women prone to respiratory problems. A study reported that in India, approximately 1.8 million people are employed through net mending, marketing, peeling, curing, preservation, trading and filleting, with women forming $48 \%$ of this total labour force and working in extremely hazardous conditions in fish processing industries ${ }^{3}$. The need of introducing labour-saving drudgery-reducing technology for post-harvest operations of finger millet, viz. ragi thresher and personal protective equipment is emphasized to make these operations easier so that workload of women can be reduced.

At the trader level, women as vendors/petty traders were selling their produce in local weekly markets in Odisha. The volume of produce ranged from 25 to $40 \mathrm{~kg}$ / week during January-March. These women collect finger millet from distant villages and sell them in weekly 'haats'. The major marketing constraints reported by the women were no price fixation by the government, poor transportation facility, no infrastructural facilities in the haats and exploitation by middlemen. The major constraints reported by the entrepreneurs/processors were the high commission charged by supermarkets, poor quality of raw materials, complex system of licensing and renewal, fluctuating prices of ragi and lack of awareness about its nutritive value. Another study observed that women play a key role in entrepreneurship for national development. In most of the developing world, women form the bedrock of the society because of their entrepreneurship. However, they are always at the receiving end of negative impact of any distressed economy ${ }^{4}$.

To strengthen the role of women in the existing finger millet value chain by forming forward and backward linkages, scientists-farm women interfaces were organized for mobilizing women for establishing finger millet processing units. One cluster of three self-help groups 
RESEARCH COMMUNICATIONS

Table 1. Change in value along the finger millet value chain

\begin{tabular}{|c|c|c|c|c|c|c|c|c|c|c|c|c|}
\hline \multirow[t]{2}{*}{ Actor } & \multicolumn{3}{|c|}{ Petty sellers (haat) } & \multicolumn{3}{|c|}{ Middlemen } & \multicolumn{3}{|c|}{ Processors } & \multicolumn{3}{|c|}{ Retailers/wholesalers } \\
\hline & $\mathrm{BP}$ & SP & Change (\%) & $\mathrm{BP}$ & SP & Change $(\%)$ & $\mathrm{BP}$ & SP & Change (\%) & $\mathrm{BP}$ & $\mathrm{SP}$ & Change $(\%)$ \\
\hline Ragi grain & 12 & 15 & 25 & 10 & 15 & 50 & 15 & 20 & 33.33 & 20 & 22 & 10 \\
\hline Ragi flour & - & - & - & - & - & - & 15 & 25 & 66.67 & - & - & - \\
\hline
\end{tabular}

$\mathrm{BP}$, Buying price; SP, Selling price.

(SHGs) from Luhaba Maliput village in Koraput district, Odisha, was formed for establishing millet processing unit and forward linkage with traders. The farm women belonged to the Bhuiya tribe. About 50 tribal families were exclusively cultivating ragi in this village, owning a land holding of 2-3 acres on an average. The productivity was found to be $2-3 \mathrm{q} /$ acre in upland. Also, $50 \%$ of the produce was retained for home consumption and $50 \%$ marketed as raw, with an income of Rs $15-20 / \mathrm{kg}$ for ragi grains. In village-level haats, the price of ragi flour was found to be Rs $25-30 / \mathrm{kg}$ (whereas in urban markets, ragi flour is Rs $80 / \mathrm{kg}$ ). Another cluster of SHGs representing the Barja tribe was formed in Muliaput village in Koraput district, wherein 20 families cultivated exclusively ragi. Two millet processing units were established in these two tribal villages, viz. Luhaba Maliput and Muliaput in Semiliguda and Nandapur blocks of Koraput district on 8 March 2017, commemorating the International Women's Day. With these interventions, the entry points for women in finger millet value chain were identified, and the women SHGs in these two villages were mobilized into two clusters. They were provided with machineries such as millet pulverizer, digital weighing machine, hot sealing machine for packaging, and other raw materials such as polythene packaging materials to start their enterprise of making ragi flour. The machineries provided could help them in making not only ragi flour, but also flour of other millets and turmeric. The units established could help the clusters of women SHGs enhance their livelihood with an increase of about $50 \%$ in their marketing margin by value addition to finger millet, specifically by making flour.

Table 1 shows the change in value along the finger millet value chain.

From the table, it can be observed that, petty traders made a margin of $25 \%$, middlemen $50 \%$, processors $33 \%$ and retailers/wholesalers $10 \%$ in ragi trading. For ragi flour, the margin was about $66 \%$. A study on the impact of value chains on gender and empowerment found that positive changes for women with respect to their access to capital, training and extension, decision-making in the production process and position in the chain could be realized ${ }^{5}$.

Agricultural value chains, rural entrepreneurship development through value-addition to agricultural commodi- ties, and taking up agriculture in business mode are gaining momentum, and have been widely recognized as a means to reduce rural poverty, and for socio-economic empowerment of farming communities, especially farm women. Finger millet has been a staple crop for millions of farm households in arid and semiarid regions of India, and is a highly nutritious source of food for the poor rural communities in the country. However, due to inadequate post-harvest technologies for value-addition, and lack of awareness, knowledge and skill among the farming communities about processing technologies to add value, finger millets are looked down as inferior or as a poor man's food. Hence capacity building and skill upgradation among farming communities, especially among farm women on post-harvest processing technologies for valueaddition, and establishing forward and backward linkages will play an important role in augmenting the food and nutritional well-being of poor households in arid and semiarid regions of India, where this cereal crop grows well.

1. Barrientos, S., Gender, flexibility and global value chains. IDS Bull., 2001, 32, 3-93.

2. Tallontire, A., Dolan, C., Smith, S. and Barrientos, S., Reaching the marginalized? Gender value chains and ethical trade in African horticulture. Develop. Pract., 2005, 15, 559-571.

3. Nag, V., Shah, P. and Nag, P. K., Risk factors and musculoskeletal disorders among women workers performing fish processing. Am. $J$. Ind. Med., 2012, 55, 833-843.

4. Orhungur, M. M., Agbe, N. N. and Egbe-Okpenge, E. G., Gender roles and biases in education in Nigeria. Benue State Univ. J. Educ., 2003, 4(1), 33-41.

5. Laven, A., Eerdewijk, A. V., Sanders, A., Wees, C. V. and Snelder, S., Gender in value chains: emerging lessons and questions. A Working Paper KIT, CIDIN, HIVOS, Agri-Pro Focus and ICCO, 2009, pp. 1-13.

Received 2 November 2018; accepted 11 March 2019

doi: $10.18520 / \mathrm{cs} / \mathrm{v} 116 / \mathrm{i} 11 / 1893-1896$ 